\title{
Kontakty Biblioteki Zakładu Narodowego im. Ossolińskich we Wrocławiu z Lwowską Naukową Biblioteką im. W. Stefanika w powojennym pięćdziesięcioleciu
}

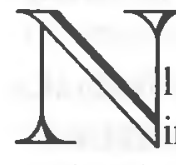
a stosunkach między Biblioteką Zakładu Narodowego im. Ossolińskich we Wrocławiu a Lwowską Naukową Biblioteką zaciążyła polityka radzieckiej Ukrainy wobec polskich dóbr kultury w latach II wojny światowej i bezpośrednio po jej zakończeniu. Znaczenie niemal symboliczne ma fakt, że powstanie Biblioteki im. W. Stefanika w styczniu 1940 r. (czyli jak się ona wówczas nazywała Lwowskiej Filii Biblioteki AN USRR) łączyło się z likwidacją Zakładu Narodowego im. Ossolińskich i oznaczało ono zawłaszczenie przez instytucję ukraińską polskiego dorobku kulturalnego tam zgromadzonego oraz zakwestionowanie praw narodu polskiego do tych zbiorów. Zarzewiem przyszłych konfliktów stał się zwłaszcza podział zbiorów lwowskiego Ossolineum dokonany przez stronę ukraińską w latach 1946-1947. W jego wyniku i przemieszczeń okresu II wojny światowej w reaktywowanym we Wrocławiu Zakładzie Narodowym im. Ossolińskich znalazło się zaledwie ok. 1/3 zbiorów lwowskiego Ossolineum, reszta pozostała w Lwowskiej Bibliotece AN USRR, w tym największy i najkompletniejszy w Polsce zbiór czasopism, prawie całość zbiorów kartograficznych i graficznych, niemal połowa zbiorów rękopiśmiennych, duża część druków XIX-XX w., a także całe archiwum Zakładu z lat 1817-1940. Nie uznanie wówczas przez stronę ukraińską praw narodu polskiego do całości zbiorów lwowskiego Ossolineum poważnie utrudniło, jeśli nie uniemożliwiło realną współpracę i trwale wypaczyło na wiele lat stosunki między obu bibliotekami. Fakt, że obie biblioteki wyrosły na tej samie bazie zbiorów lwowskiego Ossolineum i obie uznały 
się za jego spadkobiercę, stał się największą przeszkodą w nawiązaniu między nimi normalnych stosunków. Po 1946 r. Zakład Narodowy im. Ossolińskich, mimo zmiany swego statusu prawnego i siedziby, stał się w sposób niepodważalny kontynuatorem i spadkobiercą lwowskiego Ossolineum, kultywując pieczołowicie jego tradycję i historię, natomiast inaczej przedstawiała się sprawa w Bibliotece im. Stefanika, która mimo że uznała się za jedynego spadkobiercę lwowskiego Ossolineum, od samego początku swego istnienia zacierała i kwestionowała ogólnopolski, narodowy charakter tej biblioteki i zgromadzonych w niej zbiorów. Biblioteka im. Stefanika swoje prawa do zbiorów Ossolineum starała się uzasadnić przez podważenie polskiego i fundacyjnego charakteru biblioteki, w tym celu dowolnie naginając lub przemilczając fakty z dziejów Zakładu Narodowego im. Ossolińskich.

Służyć temu miała choćby teza wysunięta przez Bibliotekę im. Stefanika jakoby Józef Maksymilian Ossoliński przekazał swoją bibliotekę miastu Lwów i Ossolineum miało charakter biblioteki miejskiej. W poświęconych Bibliotece im. Stefanika publikacjach starannie unikano nawet podawania określenia „narodowy” w nazwie Zakładu Narodowego im. Ossolińskich (zastępowano go określeniem „naukowy” lub poprzestawano na nazwie „Instytut im. Ossolińskich"). Wydany w 1979 r. przewodnik po Bibliotece im. Stefanika na temat Biblioteki Zakładu Narodowego im. Ossolińskich miał do powiedzenia tylko tyle, że ,zbiory druków i rękopisów tej biblioteki do tego stopnia związane były z historią Ukrainy i Rosji, że Ukraińcy uważali ją za swoją. Biblioteka była źródłem literackiego odrodzenia Zachodniej Ukrainy: tutaj M. Szaszkiewicz, I. Wahilewicz i J. Hołowaćkyj zaznajamiali się z dziełami nowej ukraińskiej literatury i postępowej literatury Rosji”. ${ }^{2}$ Tezy te - uragające nie tylko prawdzie historycznej ale i zwykłej przyzwoitości podtrzymywane były i później, m.in. w wydanej przed kilku laty historii Biblioteki im. Stefanika. Ossolineum w świetle historyków ukraińskich to $\mathrm{w}$ istocie nie mająca właściwie nic wspólnego z kulturą polską biblioteka o międzynarodowym charakterze, która kompletowała w zasadzie literaturę w językach słowiańskich. Były tutaj także szeroko reprezentowane książki i czasopisma w językach angielskim, francuskim i niemieckim, przy czym jednak - jak zaznaczano - od samego początku założenia zbiory Ossolineum składały się przeważnie z materiałów, związanych z historią Ukrainy i Rusi. Nie ukrywano, że Biblioteka Ossolineum założona została przez polskiego magnata Józefa Maksymiliana Ossolińskiego, ale w zbieraniu książek pomagali mu i później organizowali Bibliotekę ukraińscy uczeni i bibliotekarze 
(tacy jak M. Hryniewiecki, M. Harasewicz, M. Michalewicz i I. Wahilewicz). Ponadto utrzymywana ona była ze środków pochodzących z wyzysku chłopów ukraińskich (według historyków ukraińskich głównym źródłem utrzymania Zakładu były majątki hrabiny Worcell położone w Tarnopolszczyźnie) oraz zasilana przede wszystkim zbiorami pochodzącymi z likwidowanych ukraińskich klasztorów greckokatolickich (klasztor św. Onufrego) i dlatego też z jej zbiorów korzystali przede wszystkim ukraińscy uczeni i pisarze, jak np. I. Franko. Ani słowa o tym, że oprócz Ukraińców kierowali lwowskim Ossolineum i pracowali tam jacyś Polacy, ani słowa o fundacyjnym charakterze instytucji, roli odgrywanej przez Ossolineum w życiu kulturalnym narodu polskiego jako biblioteki narodowej i polskiego instytutu naukowego w okresie zaborów, gromadzeniu polskiego piśmiennictwa głownie dzięki ofiarności polskiego społeczeństwa, działalności wydawniczej itd. ${ }^{3}$

Takie poglądy nie mogły sprzyjać nawiązaniu przyjaznych stosunków, stworzyć atmosfery wzajemnego szacunku i współpracy. Wspominam o tym tak szeroko, gdyż takie poglądy były aż do ostatnich czasów oficjalną wykładnią Lwowskiej Naukowej Biblioteki im. Stefanika i władz Republiki Ukraińskiej, służąc do kwestionowania zasadności polskich roszczeń do zatrzymanych we Lwowie zbiorów Ossolineum.

Sprawa zbiorów lwowskiego Ossolineum stała się prawdziwą kością niezgody między obu bibliotekami. Było w pełni zrozumiałe i uzasadnione, że reaktywowany we Wrocławiu Zakład Narodowy im. Ossolińskich nie mógł się wyrzec praw do swoich zbiorów zatrzymanych we Lwowie, zwłaszcza, że ogromna większość tych zbiorów nie miała nic wspólnego z kulturą i historią Ukrainy i stanowiła typowe „polonica”. Nie była to bynajmniej sprawa prestiżowa czy też okazja do szukania rozgłosu. Może problem ten nie budziłby ciaggle tak żywych namiętności, gdyby dokonany po wojnie podział zbiorów nie był tak krzywdzący dla strony polskiej, tak dotkliwie uszczuplając zbiory Ossolineum i rozbijający ich całość i integralność. Przecież nie były odosobnione przypadki, że w z kilkutomowego rękopisu jeden pozostał we Lwowie, drugi znajduje się we Wrocławiu, że z tytułu czasopiśmienniczego główny ciąg zatrzymano we Lwowie, dodatki trafiły natomiast do Wrocławia. ${ }^{4}$ Szczególnie dotkliwie odczuwany był we Wrocławiu brak archiwum zakładowego i zbioru czasopism, m.in. ze względu na utrudnienia w badaniach nad dziejami Zakładu oraz w badaniach naukowych nad dziejami kultury polskiej. Poczucie doznanej krzywdy dominowało w Ossolineum nieustannie, kiedy zbiory stworzone i zgromadzone nie mogły służyć zgodnie ze swoim przeznaczeniem narodowi pol- 
skiemu. Sprawa odzyskania tych zbiorów (a przede wszystkim archiwum zakładowego i kolekcji czasopism) nieustannie podnoszona była na posiedzeniach Rady Naukowej Biblioteki ZNiO, poruszana była w publikacjach prasowych oraz w pismach i memoriałach kierowanych przez Dyrekcję Biblioteki i Towarzystwo Przyjaciół Ossolineum do polskich władz państwowych. Trzeba tu z naciskiem podkreślić, że nigdy, niezależnie od sytuacji politycznej i wyznawanych przez siebie poglądów, żaden z dyrektorów Biblioteki Ossolineum nie wyrzekł się roszczeń do zbiorów ossolińskich zatrzymanych przez Bibliotekę im. Stefanika we Lwowie. Odzyskanie tych zbiorów było celem zarówno dla Eugeniusza Szlapaka w latach 1956-1958, ${ }^{5}$ Franciszka Pajączkowskiego w latach sześćdziesiątych, Janusza Albina pod koniec lat osiemdziesiątych, jak i w ostatnich latach dla Adolfa Juzwenki.

Byłoby jednak fałszywe przekonanie, że przedmiotem sporu były tylko zbiory znajdujące się we Lwowie. Fakt, że Biblioteka im. Stefanika uznała się za prawowitego spadkobiercę zbiorów lwowskiego Ossolineum, miało swoje dalsze reperkusje. Najbardziej spektakularnym tego przykładem była głośna w l. 1970-1971 i 1991 r. sprawa roszczeń Biblioteki im. Stefanika do rysunków Albrechta Dürera, które do 1940 r. znajdowały się w związanym z Ossolineum Muzeum im. Lubomirskich, a po wojnie znalazły się w różnych zbiorach i muzeach na zachodzie Europy i w Stanach Zjednoczonych. W publikacjach ukazujących się w prasie radzieckiej Ukrainy nie miano wątpliwości, że miejsce tych rysunków jest w lwowskim Ossolineum ,to jest w Lwowskiej Bibliotece AN USRR, jak teraz nazywa się Ossolineum". ${ }^{6}$ Nadzieje na przyjęcie tych zbiorów były w Bibliotece im. Stefanika tak duże, że podobno przygotowano tam Gabinet Dürera celem przyjęcia rysunków po ich powrocie. ${ }^{7}$ Radzieckie roszczenia wywołały wówczas poważne zaniepokojenie polskiej opinii publicznej, która w licznych publikacjach prasowych stała na stanowisku, że rysunki te stanowią niezaprzeczalną własność narodu polskiego i powinny znaleźć się w Ossolineum we Wrocławiu. ${ }^{8}$ Wiadomo także, że dyrekcja Lwowskiej Biblioteki AN URSR w trakcie rozmów prowadzonych we Lwowie w maju $1987 \mathrm{r}$. z dyrekcją Biblioteki ZNiO wykazała zainteresowanie odzyskaniem w całości zbiorów Ossolineum wywiezionych przez Niemców ze Lwowa w 1944 r. i znajdujących się we Wrocławiu, mimo że znajdowały się tam prawie bez wyjątku najcenniejsze zabytki kultury polskiej. ${ }^{9}$

Przez lata 50-te do końca lat 80-tych o nawiązaniu bezpośrednich rozmów między Wrocławiem a Lwowem w sprawie zbiorów nie mogło być 
mowy. Nie stwarzał ku temu możliwości status biblioteki Ossolineum jako biblioteki resortowej Polskiej Akademii Nauk, nie sprzyjała temu także ówczesna sytuacja polityczna. Nie rezygnując z odzyskania całości zbiorów i przypominania władzom państwowym o konieczności ich rewindykacji, Ossolineum musiało się ograniczać przez wiele lat do działań zastępczych. Takimi mogły być wymiana dubletów w zakresie książek i czasopism ${ }^{10}$ oraz mikrofilmowanie zbiorów znajdujących się we Lwowie. Wymiana międzybiblioteczna $\mathrm{z}$ bibliotekami ukraińskimi nawiązana została $\mathrm{w}$ latach pięćdziesiątych i to nie bez trudności. Swoja wymowę zresztą miało, że z inicjatywą wymiany Ossolineum zwróciło się początkowo nie do Lwowa, lecz do Biblioteki AN USRR w Kijowie w 1951 r., nie otrzymując zresztą wówczas zadawalającej odpowiedzi. ${ }^{11}$ Przez dłuższy czas do wymiany międzybibliotecznej z żadną z bibliotek ukraińskich nie dochodziło i dopiero w $1956 \mathrm{r}$. z propozycją wymiany dubletów czasopism polskich XIX-XX w. w zamian za nowe wydawnictwa polskie nieoczekiwanie zwróciła się do Biblioteki ZNiO we Wrocławiu Biblioteka im. Stefanika. Nadzieje Zakładu Narodowego im. Ossolińskich były bardzo duże - wysłany wówczas do Lwowa wykaz czasopism, których pozyskaniem zainteresowane było Ossolineum zawierał 408 tytułów. Wymiana zaowocowała przekazem w latach 19561957 przez Bibliotekę im. Stefanika kilkunastu tytułów czasopism i gazel z XIX-XX w. w ok. 340 vol., oraz 119 woluminów książek, w tym m.in. 55 egzemplarzy Gazety Narodowej z lat 1862-1913, 13 egzemplarzy Gazety Lwowskiej 1811-1828 oraz pojedynczych egzemplarzy Gazety Korespondenta Warszawskiego 1827-1830, Dziennika Ustaw i Rozporzqdzeń Krajowych 1865-1916, Gwiazdki Cieszyniskiej i Przegladu Powszechnego. ${ }^{12}$

Oczekiwania Ossolineum związane z wynianą dubletów nie zostały spełnione, gdyż zapoczątkowana w 1956 r. wymiana z Lwowską Biblioteka AN USRR z nieznanych przyczyn urwała się w dwa lata później tak samo nagle, jak się zaczęła. Po 1958 r. kontakty międzybiblioteczne z Biblioteką im. Stefanika nie były utrzymywane, aktywną i owocną wymianę prowadziło natomiast Ossolineum z Biblioteką AN USRR w Kijowie, a nawet z Biblioteką Uniwersytetu Lwowskiego im. Iwana Franki. Jak się zdaje próbą przełamania tego impasu była wizyta dyrektora Biblioteki Ossolineum F. Pajączkowskiego w Bibliotece im. Stefanika na przełomie 1965/1966 r. Nie przyniosła ona jednak żadnych rezultatów, mimo że po swoim powrocie Pajączkowski oceniał, że istnieje przychylny klimal do wymiany dubletów ossolińskich, szczególnie czasopism, za bieżącą produkcję wydawniczą. ${ }^{13}$ Okazją do zbliżenia stanowisk i nawiązania współpracy nie stały się 
także obchodzone w 1967 r. we Wrocławiu uroczystości jubileuszowe 150-lecia Zakładu Narodowego im. Ossolińskich. Nic więc dziwnego, że w latach siedemdziesiątych kontakty Ossolineum z Biblioteką im. Stefanika urwały się zupełnie, tak że nawet biblioteka ta nie była w 1977 r. wymieniana wśród bibliotek z którymi Ossolineum prowadziło wymianę zagraniczną. ${ }^{14}$ Próbę zmiany tej niekorzystnej sytuacji dyrekcja Biblioteki ZNiO podjęła w 1979 r., proponując Bibliotece im. Stefanika współpracę w zakresie wymiany publikacji oraz podejmując starania o zaproszenie jej dyrektora do Polski. ${ }^{15}$ Niestety nie wiadomo nic o tym, aby zamierzenia te doczekały się wówczas realizacji. Nic więc dziwnego, że w latach osiemdziesiątych wymiana międzybiblioteczna z Biblioteką im. Stefanika ustała niemal całkowicie. Stan ten utrzymuje się do chwili obecnej. ${ }^{16}$

Wobec nikłych szans na odzyskanie ze Lwowa zbiorów i trudności w ich dostępie od początku lat sześćdziesiątych coraz większe uznanie zdobywał pogląd o przystąpieniu do mikrofilmowania zbiorów lwowskich i w ten sposób uzupełnienia luk w zbiorach wroclawskich. Postulat ten znalazł rzeczników zwłaszcza wśród uczonych wrocławskich, którzy na forum Rady Naukowej Ossolineum przez kilkanaście lat domagali się nawiązania współpracy z Lwowską Biblioteka im. Stefanika w tym względzie i to na płaszczyźnie świadczeń międzybibliotecznych. Z wnioskami w tej sprawie występowali m.in. profesorowie Uniwersytetu Wrocławskiego Antoni Knot, Bolesław Olszewicz, Marian Jakóbicc, Władysław Floryan, Roman Lutman. ${ }^{17}$ Szczególnie wyraziście zabrzmiał w tej sprawie głos prof. Uniwersytetu Jagiellońskiego Adama Vetulaniego, który na uroczystościach jubileuszowych 1967 r. zaproponował zwrócenie się do Polskiej Akademii Nauk z postulatem o wyjednanie zezwolenia na zmikrofilmowanie i sprowadzenie do kraju wszystkich interesujących polskich uczonych materiałów. ${ }^{18}$ Uznając za najpilniejsze mikrofilmowanie zbiorów czasopism i archiwum zakładowego, proponowano nawet wysyłanie pracowników Ossolineum do Lwowa w celu przeprowadzenia odpowiednich kwerend i wytypowania materiałów archiwalnych do mikrofilmowania. ${ }^{19}$ Sprawę tę uznawano zresztą za dość łatwa do przeprowadzenia, gdyż - jak przypuszczano - mikrofilmowanie rozwinięte na szeroką skalę nie powinno napotkać na większe przeszkody, poza tym rozwiązanie ewentualnych trudności technicznych związanych z mikrofilmowaniem zbiorów we Lwowie widziano w wypożyczaniu zbiorów do Wrocławia i mikrofilmowaniu ich tutaj na miejscu. Współpraca w zakresie mikrofilmowania zbiorów lwowskich nie wyszła jednak poza sferę projektów. Wbrew opiniom wrocławskich uczonych do projektu tego dość chłod- 
no i wstrzemięźliwie odnieśli się kolejni dyrektorzy Ossolineum. Interpelowany w tej sprawie J. Albin w 1971 r. poprzestał na ogólnikowych i nic nie mówiących zapewnieniach, że ,sprawa formy udostępniania materiałów znajdujących się we Lwowie jest przedmiotem starań dyrekcji i rozwinięcie wymiany wydawnictw i mikrofilmowania może wyrównać istniejące braki" ${ }^{20}$ Obok trudności technicznych nawiązania takiej współpracy (brak odpowiedniego sprzętu w Bibliotece im. Stefanika) oraz uzyskania zgody odpowiednich władz i środków finansowych na ten cel, zadecydowały jak się zdaje przyczyny natury zasadniczej - już w 1961 r. dyrektor Ossolineum F. Pajączkowski stwierdził, że poprzestanie na rewindykacji cząstkowej (w formie dubletów i mikrofilmów), oznaczałoby to rezygnację z roszczeń do całych zbiorów zatrzymanych we Lwowie. Braku kompleksowej akcji mikrofilmowania zbiorów lwowskich nie zmieniło mikrofilmowanie pojedynczych jednostek rękopiśmiennych i archiwalnych dla potrzeb naukowych poszczególnych pracowników Ossolineum, wskutek czego znajdujące się we Wrocławiu mikrofilmy zasobów lwowskich mają nieco przypadkowy charakter i w żadnym wypadku nie odzwierciedlają faktycznego bogactwa tych zbiorów. Nie doszło także do penetracji zbiorów lwowskich przez pracowników Ossolineum pod kątem zapoznania się z ich stanem, ewidencją zasobów, czy też wytypowaniu zbiorów do ich mikrofilmowania.

Wobec braku współpracy w zakresie wymiany międzybibliotecznej i mikrofilmowania zbiorów, jedyną żywo się rozwijającą formą kontaktów między Ossolineum a Biblioteką im. Stefanika były wyjazdy do Lwowa pracowników wrocławskiego Ossolineum, częste zwłaszcza w latach sześćdziesiątych i siedemdziesiątych, w celu przeprowadzania kwerend naukowych w archiwum ZNiO. Trzeba zaznaczyć, że chociaż strona ukraińska nie stwarzała trudności w dostępie do tych materiałów, kontakty te nie przybrały jednak nigdy charakteru dwustronnej współpracy naukowej, nawet w odniesieniu do zagadnień mogących zainteresować obie strony, przede wszystkim ze względu na reprezentowany przez Bibliotekę im. Stefanika stosunek do historii Ossolineum. Badania nad dziejami lwowskiego Ossolineum stały się wyłączną domeną wrocławskiego środowiska ossolińczyków i zaowocowały one licznymi i wartościowymi pracami Józefa Adama Kosińskiego, Krystyny Korzon, Henryka Lapińskiego, Ireny Lewandowskiej-Jaraczewskiej, Józefa Wojtala i in. Posiadająca natomiast archiwum ZNiO Biblioteka im. Stefanika nie podjęła żadnych badań naukowych nad dziejami tej instytucji. Może jest i to też odpowiedzią na pytanie, dlaczego nigdy w ciągu pięćdziesięciu lat nie doszło do wspólnej sesji naukowej 
czy też wymiany poglądów na wspólne dla obu bibliotek tematy.

Przełom we wzajemnych stosunkach między ZNiO a Biblioteka im. Stefanika otworzyły zmiany polityczne w ZSRR zapoczątkowane w połowie lat osiemdziesiątych przez Michaiła Gorbaczowa. Postępująca odwilż polityczna w ZSRR uaktualniła sprawę scalenia we Wrocławiu zbiorów Ossolineum. Ówczesna sytuacja zdawała się sprzyjać nawiązaniu bezpośrednich kontaktów w tej sprawie między obu bibliotekami i uregulowaniu jej z poszanowaniem interesów obydwu stron, zwłaszcza, że już na początku 1987 r. do Wrocławia zaczęły napływać wiadomości o przygotowaniu w Bibliotece im. Stefanika jakiejś dużej partii zbiorów ossolińskich dla przekazania ich Bibliotece $\mathrm{ZNiO}$ we Wrocławiu, wśród których miały być cenne pamiątki piśmiennictwa polskiego drukowane i niedrukowane, w ilości ok. 2500 jednostek. ${ }^{21}$

Chcąc podkreślić swoją wolę i chęć utrzymania współpracy w tej mierze, Biblioteka Ossolineum we Wrocławiu przekazała w kwietniu 1987 r. ze swoich zbiorów Bibliotece im. Stefanika 9 starych druków i 3 rękopisy pochodzące z kręgu kultury rosyjskiej i ukraińskiej. Odbiór ossolinianów pod koniec maja we Lwowie rozwiał jednak wszelkie nadzieje i oczekiwania dyrekcji Biblioteki ZNiO. Okazało się bowiem, że tak szumnie zapowiadany dar objął tylko druki XIX-XX w., w większości nie przedstawiające większej wartości naukowej czy historycznej, w tym 1000 książek z dawnych nierozprowadzonych przed 1939 r. nakładów wydawnictwa Ossolineum. Jak pisał dyrektor Biblioteki ZNiO J. Albin w swoim sprawozdaniu „w trakcie wizyty we Lwowie okazało się, że strona ukraińska do rozmów w sprawie wymiany narodowych dóbr kultury nie jest przygotowana. Wykazała wręcz zdziwienie, że podnosi się sprawę zbiorów ossolińskich, uważaną przez nią ostatecznie za zamkniętą. Dlatego do rzeczowej, szczegółowej wymiany zdań w kwestii roszczeń polskich i ewentualnych dezyderatów ukraińskich nie doszło". Mimo że zgłoszone wówczas przez dyrektora J. Albina propozycje odnośnie zbiorów były postawione bardzo ostrożnie i oględnie - nie było w nich mowy o rewindykacji, lecz jedynie o wymianie pomiędzy Polską a Ukrainą narodowych dóbr kultury - sprawa ta nie spotkała się z większym zainteresowaniem strony ukraińskiej.

Jedynym efektem rozmów było podpisanie 29 maja 1987 r. we Lwowie przez dyrektorów obu bibliotek ,,protokołu o współpracy w dziedzinie kultury i nauki", przewidującego współpracę zakresie wymiany książek i publikacji, działalności informacyjnej oraz badań księgoznawczych. Obaj dyrektorzy wyrazili też ustnie zainteresowanie wymianą mikrofilmów. Zgodnie z tym J. Albin zaproponował wymianę mikrofilmów jednostek rękopiśmien- 
nych interesujących pracowników naukowych obydwu stron - mikrofilmowanie miało objąć przede wszystkim materiały rękopiśmienne, które w wyniku przemieszczeń okresu II wojny i podziału zbiorów ossolińskich zostały rozbite i znajdowały się we fragmentach w obydwu bibliotekach. Na taką wymianę deklarował gotowość wykonania 8000 klatek rocznie, w zamian licząc na otrzymanie podobnej liczby klatek z Biblioteki im. Stefanika. Inicjatywa ta jednak, tak jak i poprzednie, skończyła się faktycznie na deklaracjach, mimo że zainteresowany tą współpracą Albin gorąco zapraszał dyrekcję Biblioteki im. Stefanika do zamówienia we wrocławskim Ossolineum mikrofilmów interesujących ją materiałów, choćby w oparciu o drukowane inwentarze rękopisów Biblioteki ZNiO we Wrocławiu. Tak szeroko planowana wymiana mikrofilmów ograniczyła się bowiem do wykonania przez Bibliotekę im. Stefanika mikrofilmów materiałów dot. Towarzystwa Oświaty Ludowej z lat 1868-1872 znajdujących się w papierach Tadeusza Romanowicza, a przez Ossolineum tylko jednego starego druku. Biblioteka ZNiO nie uzyskała ani potwierdzenia odbioru wysłanych książek, ani też odpowiedzi na propozycje kontynuowania i rozszerzenia współpracy. Wydaje się że powód urwania się tej współpracy nie leżał po stronie polskiej, gdyż to najwyraźniej strona ukraińska - mimo zachęt ze strony dyrekcji Ossolineum nie była zainteresowana tą formą współpracy międzybibliotecznej. Było to o tyle dziwne, że w Ossolineum znajdowało się dużo materiałów dotyczących historii Galicji, mogących zainteresować uczonych ukraińskich i znacznie wzbogacić zbiory Biblioteki im. Stefanika. Załamania się tej współpracy należy bardzo żałować, gdyż mogła ona przynieść efekty wymierne, przynajmniej częściowo satysfakcjonujące obie strony.

Kolejną okazją do zaprezentowania stanowiska Ossolineum była wizyta we Wrocławiu w marcu 1988 r. ministra kultury Ukraińskiej SRR Jurija Olenienki. W trakcie wizyty w Bibliotece Ossolineum na przedstawione przez dyrekcję Biblioteki dezyderaty odnośnie zbiorów znajdujących się we Lwowie, Olenienko zgodnie z oficjalną linią zakwestionował polski charakter zbiorów Ossolineum we Lwowie, uważając, że spora ich część miała charakter ponadnarodowy i słowiański. Jednocześnie zapowiedział jednak rozważenie tej kwestii przez specjalistów oraz sugerował nawiązanie i rozwijanie bezpośredniej współpracy między Ossolineum a Biblioteką im. Stefanika m.in. w zakresie wymiany druków zbędnych. Wizyta zakończyła się więc niczym, nie przynosząc oprócz zdawkowych zapewnień Olenienki wymiernych rezultatów. ${ }^{25}$ Próby nawiązania bezpośredniej współpracy z Biblioteka im. Stefanika okazały się jednak - jak wcześniej zaznaczyłem 
- bezskuteczne.

Nadzieje na przełamanie impasu we wzajemnych stosunkach zdawały się stwarzać zmiany polityczne lat 1989-1990. W trakcie kilkakrotnych wizyt dyrektora Zakładu Narodowego im. Ossolińskich we Lwowie i przeprowadzonych rozmów z dyrektorem Biblioteki im. Stefanika Łarysą Kruszelnicką postanowiono nawiązać bliską współpracę między obydwiema bibliotekami. ${ }^{26} \mathrm{~W}$ trakcie wizyty w Ossolineum wicedyrektora Biblioteki im. Stefanika Tarasa Pasławskiego doszło do podpisania w dniu 5 marca 1993 r. listu intencyjnego o współpracy obu bibliotek, przede wszystkim w dziedzinie naukowej i wymiany informacji na temat własnych zbiorów. Mimo podpisania tej umowy do zbliżenia stanowisk i nawiązania rzeczywistej współpracy jednak jak dotychczas nie doszło. Nie doszło także do uzgodnienia stanowisk w najważniejszej dla Ossolineum sprawie - scalenia wszystkich jego zbiorów we Wrocławiu.

Tak więc po pięćdziesięciu latach od otrzymania ze Lwowa części zbiorów wydaje się, że sprawa zbiorów Ossolineum i polskiego dorobku kulturalnego we Lwowie nadal znajduje się w punkcie wyjścia.

\section{Ac if te}

\section{Przypisy:}

${ }^{1}$ Nazwa ta obowiązuje od 1971 r. Poprzednio biblioteka ta nosiła następujące nazwy: Lwowska Filia Biblioteki AN USRR (1940), Lwowska Biblioteka AN USRR (1944), Lwowska Państwowa Naukowa Biblioteka Ministerstwa Kultury USRR (1963) i Lwowska Państwowa Naukowa Biblioteka AN USRR (1969).

${ }^{2}$ Lwiwśka Naukowa Biblioteka im. W. Stefanyka AN USRR. Putiwnyk, red. E. M. Stasjuk, Kyiw 1979, s. 6.

${ }^{3}$ Lwiwśka Naukowa Biblioteka im. W. Stefanyka AN USRR. Istorycznyj narys, red. M. W. Lizaneć, Kyiw 1989, s. 15-17.

${ }^{4}$ Zob. M. Matwijów, Walka o lwowskie dobra kultury w latach 1945-1948, Wrocław 1996, s. 107-113.

${ }^{5}$ Archiwum Biblioteki ZNiO we Wrocławiu (dalej: AZNiO), protokół posiedzenia Rady Naukowej 3 X 1956.

${ }^{6}$ Komsomolskje Znamja, 17 II 1970, s. 3. Por. też Lwiwśka Naukowa Biblioteka im. W. Stefanyka AN URSR (1940-1980 rr.). Pokażczyk wydań biblioteki ta literatury projiji dijalnist', Lwiw I982, s. 68-69.

${ }^{7}$ Frankfurter Allegemeine Zeitung, nr 51 z 2 III 1971. 
${ }^{8}$ Życie Warszawy, 4 II 1970.

${ }^{9}$ AZNiO, Pismo J. Albina do Dyrektora Departamentu Książki i Bibliotek MKiS, 15 VI 1987.

${ }^{10}$ Należy tu zaznaczyć, że Biblioteka im. Stefanika dysponowała ogromnymi zasobami dubletów polskich książek i czasopism XIX-XX w., pochodzącymi ze znacjonalizowanych i ,skoncentrowanych" w l. 1939-1941 bibliotek prywatnych i podworskich, które zmagazynowane zostały w kościele Jezuitów we Lwowie.

${ }^{11}$ AZNiO, Wymiana zagraniczna 1947-1953, k. 183, 185.

${ }^{12}$ AZNiO, Wymiana zagraniczna 1956-1957, k. 22-23, 50, 158, 171, 177, 194, 225, 308.

${ }^{13}$ AZNiO, protokół posiedzenia Rady Naukowej 14 II 1966.

${ }^{14}$ Sprawozdanie Biblioteki ZNiO za 1977 r.

${ }^{15}$ AZNiO, protokół posiedzenia Rady Naukowej 10 IV 1979.

${ }^{16}$ Informacja kierowniczki Działu Gromadzenia Druków Zwartych XIX-XX w. ZNiO Ireny Gybej.

${ }^{17}$ AZNiO, Protokół posiedzenia Rady Naukowej 3 III 1976.

${ }^{18}$ AZNiO, Materiały dot. sesji naukowej 1967.

${ }_{19}$ AZNiO, Protokoły posiedzeń Rady Naukowej $14 \mathrm{~V}$ 1963, 10 IV 1965, 13 III 1970, 1 III 1971, 3 III 1976.

${ }^{20}$ AZNiO, Protokół posiedzenia Rady Naukowej I III 1971.

${ }^{21}$ Sprawozdanie Biblioteki ZNiO za rok 1987.

27 AZNiO, Pismo J. Albina do M. W. Lizańca, 23 VI 1987.

${ }^{23}$ AZNiO, Pismo J. Albina do M. W. Lizańca, 22 III 1988.

${ }^{24}$ Sprawozdanie Biblioteki ZNiO za $1988 \mathrm{r}$.

${ }^{25}$ AZNiO, Sprawy biblioteczne za 1988 r., Notatka służbowa J. Albina z wizyty J. A. Olenienki w Bibliotece ZNiO w marcu $1988 \mathrm{r}$.

${ }^{26}$ Sprawozdanie Biblioteki ZNiO za 1992 r.; AZNiO, Pismo A. Juzwenki do Ł. Kruszelnickiej 24 IX 1992. 